\title{
EVOLUTION OF FAMILY BUSINESSES - A 3D THEORETICAL APPROACH
}

\author{
Júlia Tobak*, András Nábrádi \\ Department of Business Management, Faculty of Economics and Business Administration \\ University of Debrecen, Debrecen, Hungary \\ tobak.julia@econ.unideb.hu \\ nabradi.andras@econ.unideb.hu
}

\begin{abstract}
According to international literature there are many researches about family businesses. Examining and evaluating these kinds of businesses is a complex task because it is hard to take into account every influencing factor which have an impact on the operation of family businesses. The purpose of this study is to present a new theoretical method and model which is applicable to measure the development of family businesses from three dimensions: (1) family, (2) business and (3) ownership. The new theoretical model is suitable for carrying out such cross-sectoral and international comparative statistical analyses. The three attributes of family businesses may be measured, evaluated and analyzed separately and/or in combination. It is suitable for doing aggregated analysis of one or more companies. The (1) family dimension presents wich generation/generations operates the business. The dimension of (2) business shows the level of separation of tasks between family and non-family members and gives an answer how the management and the ownership functions are separated. The (3) ownership dimension shows the ownership state of examined businesses and can clarify the stage of the ownership structure. The simultaneous or separate examination of dimensions can assist to family businesses to measure their own status. The TONA model is applicable to measure the evolution of family businesses and can show the differences between sectors or countries in an illustrative way.
\end{abstract}

Keywords: family businesses, new theoretical method, evaluating dimensions, cross-sectoral analysis, international comparative analysis, TONA model

JEL Classification: $C 51, D 21$

\section{Introduction}

On Fortune's list of the world's 50 largest businesses, among such corporations of global scale and reputation as, for example, Apple, HP, Amazon, AXA, Allianz, the Bank of China, Daimler, Toyota, Honda, Ford Motor, Royal Dutch Shell, Exxon Mobil, Samsung, and GE, there are some that are in family ownership. These companies include Wal-Mart, Volkswagen, Berkshire Hathaway, Ford and Exor, which operate under family control (Datashown, 2016). One of the oldest American companies is in the hands of the Zildjian family, cymbal-makers originally from Turkey, which is already at the 16th generational transition. Approximately one-third of the 500 companies on the American S\&P stock market index are also family businesses. What might be the world's oldest family business is the 1300-year-old Houshi hotel and spa in Japan, which has been operating for 46 generations (vs.hu, 2015).

The registered headquarters of the world's top family businesses are located in the G20 countries (with the exception of Switzerland), in the United States of America, Brazil, Canada, China, France, Germany, India, Italy, Japan, Mexico, South Korea, Switzerland, Denmark and the Benelux countries.

\footnotetext{
* Corresponding author: Júlia Tobak
} 
From among the newly industrialized BRICS countries, there is hardly any information available on family businesses in Russia and the South African Republic. The PwC Network (PricewaterhouseCoopers) surveyed the situation of Russian private and family businesses in 2014-2015 (PwC, 2014). The annual turnover of more than half of the 57 businesses with a strong market position which were examined exceeded USD 101 billion. The survey typically included young companies with a history of only 20 years, with only a handful of them being 50 years old. It may also follow from the above that the first generation is still present in $95 \%$ of them, and there was no third- or fourth-generation company in the sample (PwC, 2014). On the basis of their distribution among different industries, the majority of them are active in manufacturing and commerce. The businesses surveyed are present, among other fields, in diversified industrial products, agriculture and the logistics sector. It also emerges from the survey that only $26 \%$ of the respondent companies have considered the option of transferring the business within the family (PwC, 2014).

On the basis of the information available on the website of FABASA (The Family Business Association of South Africa), the list of Nsehe (2014) on the 10 leading companies in Africa, as well as the 2016-2017 survey conducted by PwC (2017), it can be concluded that South African family businesses constitute the backbone of the African economy. The list of leading family businesses in Africa includes companies with annual revenues of USD 50 million or more, with the share capital controlled by family members in at least the second generation, and the family controlling at least $30 \%$ of the company's voting. The businesses on the top 10 list are active in the luxury goods market, and in construction, agriculture and banking.

Family businesses operating in different regions of the world have to face a variety of economic, political, social and cultural challenges.

The facts and figures are summarised on the basis of the 2017 survey conducted by Ernst and Young (EY, 2017) for the individual regions, in which the characteristics of the TOP 500 family businesses (average age, GDP produced, employee percentage) are presented. Based on a distribution according to sectors, most of the world's top 500 family businesses are active in the secondary sector, with the fewest in the primary sector.

On the basis of the available data, the top 25 family businesses in the global ranking generated an average of nearly USD 101 billion in 2015.

According to the Motion For A Resolution By The European Parliament (2015), family businesses contribute to economic stability; in some EU Member States they account for a large share of the total turnover of all businesses and thus make a significant contribution to job retention, creation and growth and to the economic success of the country concerned. They are engaged in transnational activities, "a significant share of family businesses in Europe have a transnational dimension and carry out their activities in different Member States".

They make a major contribution to the competitiveness of Europe, and play a significant role in the private sector, as they account for the largest proportion of job opportunities. They are flexible and able to adapt quickly to changes in the eco-social environment. Their equity ratio is significantly higher than in case of non-family businesses. $87 \%$ of family businesses are convinced that maintaining control of the business is one of the key factors of success.

The motion highlights its recommendations concerning the challenges faced by family businesses, such as the issues of education and taxation, which are important from the point of view of business continuity. It also includes a recommendation for inheritance law, which is an issue belonging to the competence of Member States, and emphasises the dangers inherent in excessive bureaucracy.

The presence of family-owned enterprises has a significant impact on the operation of the economy as a whole. There is a growing body of research published in the international literature related to the operation of family businesses; however, no research findings are known to provide an international and cross-sectoral aggregated analysis of family-owned 
enterprises. The aim of this paper is to present the TONA model (TONA is an acronym from the initials of the authors' name - Tobak, Nábradi), which is suitable for carrying out such cross-sectoral and international comparative statistical analyses.

\section{Literature review}

The family, as an institutional system, has been the basic unit of society since prehistoric times.

Family businesses are a popular form of enterprise throughout the world. There are numerous definitions of family businesses, but there is no standardized, universally accepted one. We can find, however, some common elements in all definitions that need to be taken into consideration and examined to determine whether an organization is a family business or not (Miller et al., 2007; Cano-Rubio et al., 2017; Csákné, 2013; Tobak et al., 2018). Some of the generally accepted elements used in the definition of family businesses concern ownership, management, control, generations, and the intention to pass the business down as an inheritance within the family (Ramadani and HOY, 2015; De Massis et al., 2012; Nagy, 2007). The family business is an organization in which the control and management tasks are generally provided by multiple members of the same family - even across multiple generations (Miller et al. 2007).

A family business is an enterprise in which the majority ownership and/or majority control belongs to the same family, and at least one family member actively works in the business. In the case of traditional businesses, we can only talk about the relationship of ownership and business, while in case of family enterprises, we can speak of the relationship/combination of family, business and ownership. These three concepts have a determining role in the definition of family businesses. The so-called "three-circle model" plays a key role from the point of view of our research project (Tagiuri and Davis, 1982; Matsuhashi, 2013).

Gersick et al. (1996) drew up their model based on an examination of the life cycles of businesses. Their model depicts family businesses in the three dimensions already discussed (family, business and ownership), and also makes it possible to conduct analyses according to the three dimensions.

On the basis of their approach, family businesses can be of the following 4 types:

- first-generation businesses owned and managed by the founder;

- fast growing, established businesses owned by siblings;

- complex enterprises owned by a consortia of mature cousins;

- businesses preparing for generational succession, controlled by a family preparing to hand the business over (Csákné, 2013; Tobak et al., 2018; Nábrádi et al., 2016).

\section{Methodological approach}

The purpose of this paper is to present a theoretical model. Taking the work of Gersick et al. (1996) as a basis, the depiction according to the three dimensions has been developed further in the interest of elaborating a newer method suitable for cross-sectoral and international comparative analyses. The TONA model makes it possible to analyse family-owned businesses along the family - business - ownership dimensions (Figure 1). 


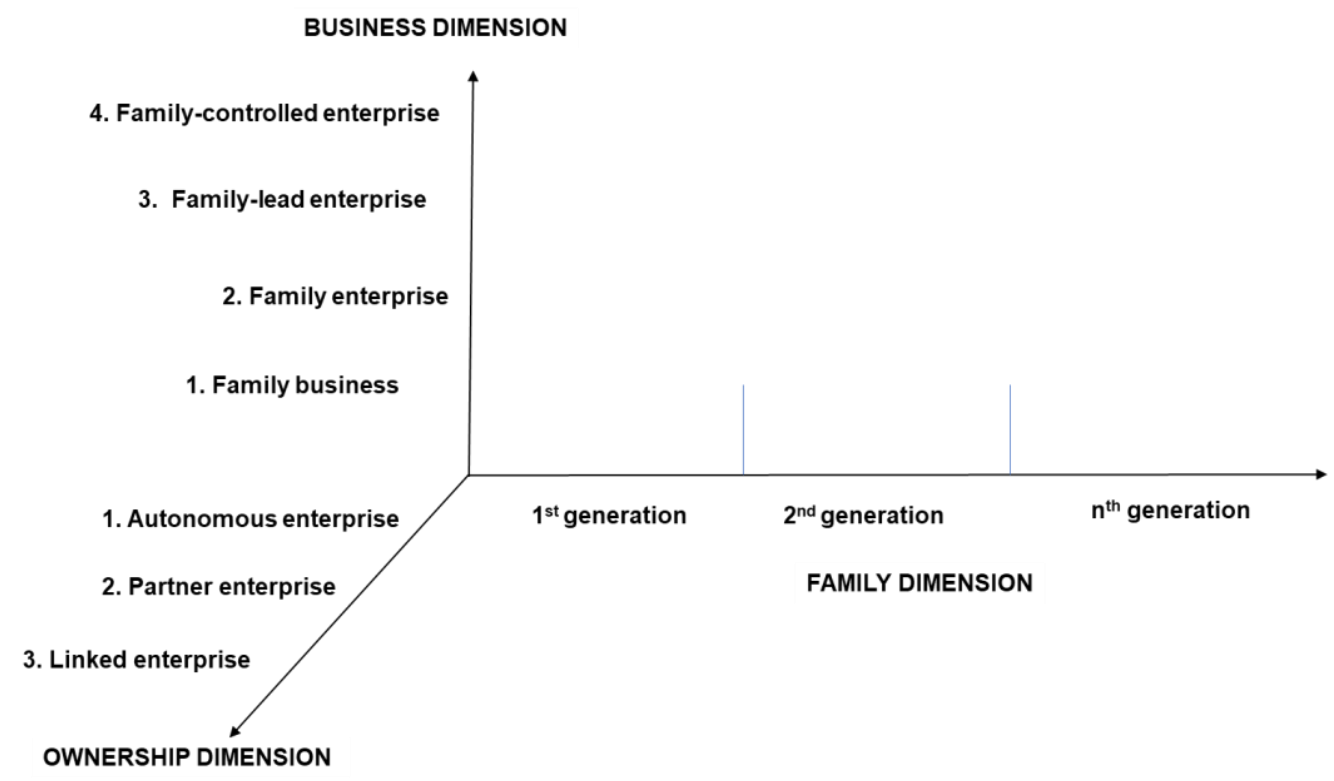

Figure 1: TONA model

Source: Authors' own editing (2018)

The TONA model allows attributes of family businesses to be measured, evaluated and analysed separately and/or in combination. The model is suitable for making an aggregated analysis of one or more companies. The simultaneous or separate examination of the development of dimensions can assist family businesses in measuring their own status and helps to compile a nationally relevant and comparable database. With this method it would be possible to make a cross-sectoral and international comparative statistical analysis of family-owned enterprises.

The TONA model is applicable to measuring the evolution of family businesses and can show the differences between sectors or countries in an illustrative way.

In order to conduct comparative analyses, it is necessary to survey the members of the family business sector. For the analysis and joint depiction of all three dimensions, we must examine which life cycle of maturity/development the businesses are in.

\subsection{Family}

In the model set up by Gersick et al. (1996), the stages of family development can be described by four separate phases building upon each other.

The (1) family dimension is defined by the sequential number of the generation operating the business at that point. If the aim is to carry out cross-sectoral or international comparative, aggregated analyses, it is sufficient to answer the question:

"Which generation is currently operating the family business?"

The TONA model is also suitable for determining and expressing in a quantitative way, as accurately as possible, where the family business currently stands in the process of generational succession.

However, it should be added as a general remark that the generational succession should only be expressed as a percentage when individual analyses are carried out. 


\subsection{Business}

As proposed by Gersick et al. (1996), the business axis can be divided into 3 stages. The start-up, expansion/formalisation and maturity stages can be interpreted independently from the form of the business. When drawing up the development stages in the business dimension of the TONA model, the development lifestyle stages formulated by the were taken into consideration. In putting together the content of the dimension Family Business Network (FBN-H, 2017), an important aspect was to emphasize that the business operated on family foundations, and definitely complies with the definition describing family businesses.

The dimension of (2) business shows the level of separation of tasks between family and non-family members. That dimension gives an answer to the question of how the management and the ownership functions are separated. The development of today's family businesses can be divided into four stages (FBN-H, 2017). A business may be placed in the various stages of development on the basis of the ownership shares of the family members, as well as what is known about their participation in the operational, tactical and strategic activities; the individual stages are separated on the basis of these characteristics. In the course of establishing the characteristics of the individual stages, properties referring to the size of the business are also included (European Commission, 2005) (Table 1).

Table 1: The characteristics of the development stages of the family company according to business dimension

\begin{tabular}{|c|c|c|c|c|c|c|}
\hline $\begin{array}{c}\text { Number } \\
\text { and name } \\
\text { of the } \\
\text { stage }\end{array}$ & $\begin{array}{c}\text { Present } \\
\text { generations }\end{array}$ & $\begin{array}{c}\text { Percentag } \\
\text { e of family } \\
\text { ownership } \\
(\%)\end{array}$ & $\begin{array}{l}\text { Company } \\
\text { size }\end{array}$ & $\begin{array}{l}\text { Decision } \\
\text { making of } \\
\text { family } \\
\text { members }\end{array}$ & Management & $\begin{array}{l}\text { TONA } \\
\text { value } \\
\text { of the } \\
\text { stages } \\
*\end{array}$ \\
\hline $\begin{array}{l}\text { 1. Family } \\
\text { business }\end{array}$ & $1^{\text {st }}$ & $100 \%$ & $\begin{array}{l}\text { micro and } \\
\text { small-sized }\end{array}$ & $\begin{array}{c}\text { operational } \\
\text { tactical, } \\
\text { strategic }\end{array}$ & family & $\begin{array}{l}1 / 4=0 \\
25\end{array}$ \\
\hline $\begin{array}{l}\text { 2. Family } \\
\text { enterprise }\end{array}$ & $1^{\text {st }}$ and $2^{\text {nd }}$ & $51 \%$ & $\begin{array}{l}\text { micro and } \\
\text { SMEs }\end{array}$ & $\begin{array}{c}\text { operational } \\
\text { tactical, } \\
\text { strategic }\end{array}$ & $\begin{array}{l}\text { family and } \\
\text { external }\end{array}$ & $\begin{array}{c}2 / 4=0 \\
5\end{array}$ \\
\hline $\begin{array}{c}3 . \\
\text { Family-lea } \\
d \\
\text { enterprise }\end{array}$ & $\left(1^{\mathrm{st}}\right), 2^{\text {nd }}, 3^{\text {rd }}$ & $51 \%$ & $\begin{array}{l}\text { micro, } \\
\text { SMEs and } \\
\text { large }\end{array}$ & $\begin{array}{l}\text { mainly } \\
\text { strategic, } \\
\text { (less } \\
\text { operational } \\
\text { and } \\
\text { tactical) } \\
\end{array}$ & mainly external & $\begin{array}{l}3 / 4=0 \\
\quad 75\end{array}$ \\
\hline $\begin{array}{l}4 . \\
\text { Family-con } \\
\text { trolled } \\
\text { enterprise }\end{array}$ & $\begin{array}{c}\left(1^{\text {st }}, 2^{\text {nd }}\right), 3^{\text {rd }} \\
\mathrm{n}^{\text {th }}(\text { at least } \\
2-3 \\
\text { generations } \\
\text { are working } \\
\text { together) }\end{array}$ & $51 \%$ & $\begin{array}{l}\text { micro, } \\
\text { SMEs and } \\
\text { large }\end{array}$ & strategic & external & $4 / 4=1$ \\
\hline
\end{tabular}

${ }^{*} \mathrm{~B}=$ business (current number of the stage/4)

Source: Authors' own work

\subsection{Ownership}

In the interpretation of the classic model, the (3) ownership axis separates 3 categories. In defining the development statuses, Gersick et al. (1996) placed family and other relationships at the centre, and therefore the categories of controlling owner, sibling partnership and cousin consortium were formulated in their model. 
The stages expressing the dimension were changed to align with the purpose of the paper. It was an important consideration on the part of the authors that it should be easy to measure and delimit the stages of ownership, and the pertinent information should be accessible potentially on the basis of other databases. The European Commission published the categories describing ownership shares in the SME Handbook (European Commission, 2005).

The definition of SMEs distinguishes three categories of enterprises, each of which corresponds to a type of relationship that may connect one enterprise with another. The distinction is necessary to obtain a clear picture of the ownership status of the business. This dimension shows the ownership state of examined businesses and can clarify the stage of the ownership structure. It can show the type of the family enterprises. The three categories that can express the ownership characteristics are the autonomous, the partner and the linked types of companies.

In the case of this dimension, once again, objective measurability was an important consideration, and therefore an index number was assigned to each category to describe it (Table 2).

Table 2: The ownership dimension

\begin{tabular}{|l|c|c|c|}
\hline $\begin{array}{l}\text { Name of } \\
\text { the stage }\end{array}$ & $\begin{array}{l}\text { Capital share in other } \\
\text { enterprises }\end{array}$ & $\begin{array}{l}\text { Number of } \\
\text { the stage }\end{array}$ & $\begin{array}{l}\text { TONA value } \\
\text { O=Ownership } \\
\text { current number of the } \\
\text { stage/3 (number of stages) }\end{array}$ \\
\hline Autonomous & $0-25 \%$ & 1 & $1 / 3=0,33$ \\
\hline Partner & $25-50 \%$ & 2 & $2 / 3=0,67$ \\
\hline Linked & $>50 \%$ & 3 & $3 / 3=1$ \\
\hline
\end{tabular}

Source: Authors' own work

For the assessment of these three ownership categories, it is necessary to find out about the ownership of any other enterprise that the family business may have a capital share in. If that other enterprise is also owned by another family member, both enterprises need to be examined in aggregate.

In case of questions of ownership, it is also important to consider control in the legal sense of the word. It is on the basis of control that we can decide whether the given business is to be considered as a linked company. It is not only the company's capital or participation that need to be examined, but also the control exercised over the other business.

\section{Theoretical cases}

The interpretation in the TONA model can be applied for the analysis of the dimensions separately and also in aggregate. There are some combinations of cases the interpretation of which is not possible. For example, on the basis of the definitions as described, a first-generation family business cannot be considered a family-led or family-controlled enterprise, and in this case the principle of development life cycles will be applicable. Figure 2 shows a few fictitious cases. The fictitious cases may describe an individual enterprise, but are also suitable for the comparison of the family businesses of the primary, secondary and tertiary sectors in such a way that the averages of the values of the businesses analyses are used. 


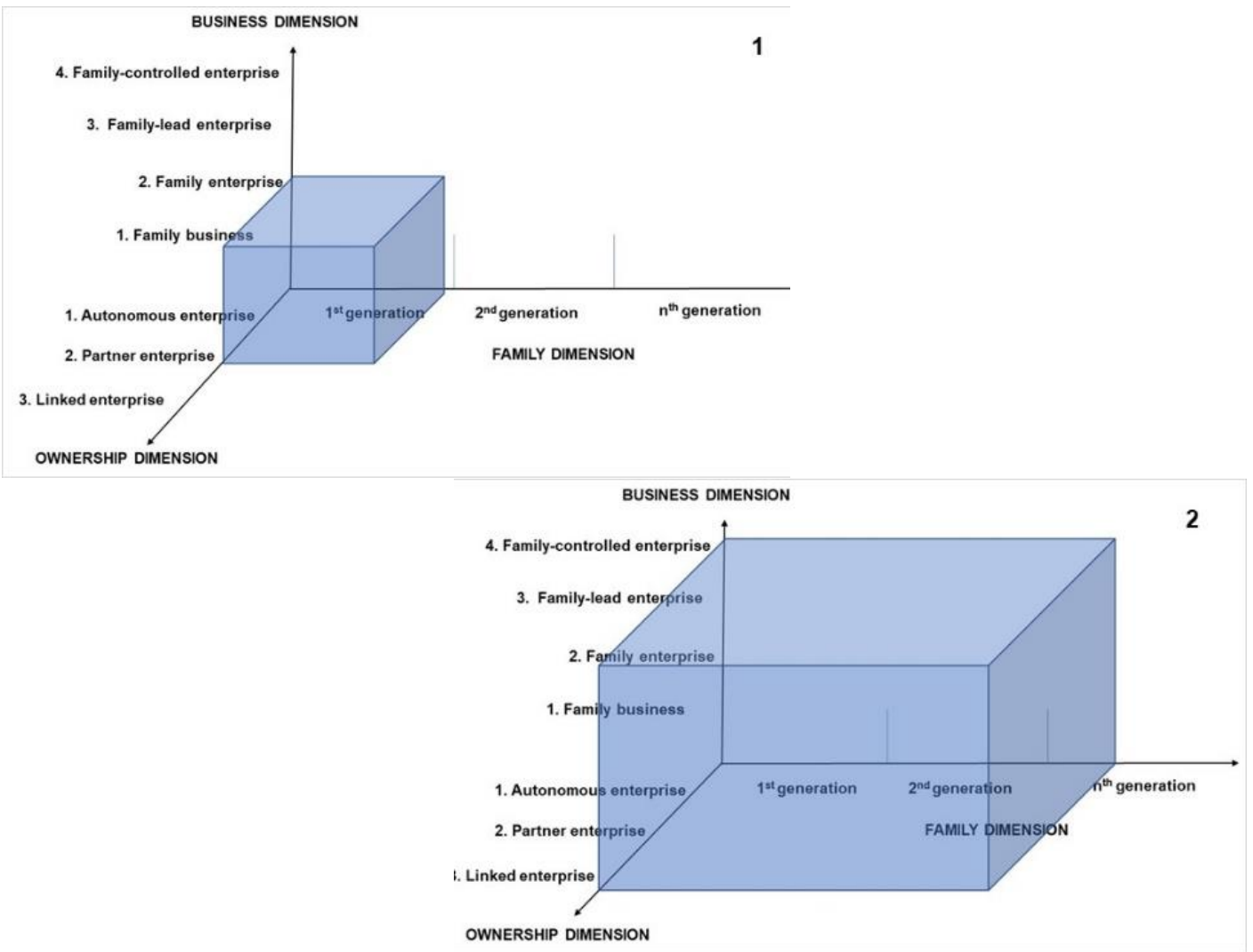

Figure 2: Examples to illustrate the TONA model

Source: Authors' own editing

The aggregated TONA value can show the volume of the rectangular and express the state of the examined business or businesses (individual family businesses, company groups, sectors, industries or nations) in an illustrative and objective way.

In Table 3, two fictitious, theoretical cases are presenting the interpretation and explanation of the TONA value.

Table 3: The explanation of the fictitious examples

\begin{tabular}{|c|c|c|c|c|c|}
\hline \multirow[b]{2}{*}{$\begin{array}{c}\text { Case } \\
\text { no. }\end{array}$} & \multirow[b]{2}{*}{ Description } & \multicolumn{3}{|c|}{ TONA values of the dimensions } & \multirow[b]{2}{*}{$\begin{array}{c}\text { Aggregated } \\
\text { TONA value } \\
\text { Volume of the } \\
\text { rectangle } \\
\left(\mathrm{F}^{\star} \mathrm{B}^{\star} \mathrm{O}\right)\end{array}$} \\
\hline & & $\begin{array}{l}\text { Family } \\
\text { (F) }\end{array}$ & $\begin{array}{l}\text { Business } \\
\text { (B) }\end{array}$ & $\begin{array}{l}\text { Ownership } \\
\text { (0) }\end{array}$ & \\
\hline 1. & $\begin{array}{l}\text { First-generation family } \\
\text { enterprise operating in the } \\
\text { form of a partner company }\end{array}$ & 0.8 & $2 / 4=0,5$ & $2 / 3=0,67$ & 0,268 \\
\hline 2. & $\begin{array}{l}\mathrm{n}^{\text {th }} \text {-generation linked } \\
\text { company, which can already } \\
\text { be placed in the category of } \\
\text { family-controlled enterprises }\end{array}$ & $\mathrm{N}$ & $4 / 4=1$ & $3 / 3=1$ & $1 \mathrm{n}$ \\
\hline
\end{tabular}

Source: Authors' own editing based on fictitious cases (Figure 2.) 


\section{1. Conclusions}

The paper proposes a methodology for the assessment of the development/maturity life cycles of family-owned enterprises. The method, which is suitable for carrying out comparative statistical analyses, allows us to make an individual or aggregated interpretation of the three dimensions. The family-business-ownership dimensions express the current condition in an objective, quantitative way, which is applicable to individual family businesses, company groups, sectors, industries or entire nations. With the help of the model, cross-sectoral and international comparative statistical analyses may also be conducted.

The family dimension of the methodology, together with the fine-tuning, may help individual family enterprises in assessing where exactly they stand in the process of generational succession. Knowledge of this may be beneficial in thinking over/elaborating the strategy of generational succession.

When conducting international comparative analyses, it may be worthwhile and also enlightening to examine and/or ask the question whether the enterprise is to be considered as a conglomerate. Presumably, this may be typical in the case of family businesses launched several generations ago, which are characterised by familial relationships which are so extensive they make it possible for them to be active in several sectors.

Further research needs to be conducted to test the usability of the TONA model in practice. Before commencing the practical testing of the theoretical model, it is necessary to engage in primary and secondary research, to prepare smaller analyses and case studies, as well as to obtain feedback in connection with the model, which will allow the refining of the method, and a more accurate and more detailed definition of the factors determining the dimensions.

\section{Acknowledgement}

The authors express their gratitude to the Faculty of Economics and Business Administration of the University of Debrecen. This work was supported by EFOP3.6.3-VEKOP-16-2017-00007 - "Young researchers for talent"-Supporting careers in research activities in higher education program.

\section{References}

Cano-Rubio, M., Fuentes-Lombardo, G., Vallejo-Martos, M.C., 2017. Influence of the lack of a standard definition of "family business" on research into their international strategies. European Research on Management and Business Economics 23 (2017), pp. 132-146. DOI:10.1016/j.iedeen.2016.10.002

Csákné Filep J., 2013. Családi vállalkozások - fókuszban az utódlás [Family enterprises Focus on succession]. Doctoral dissertation. Corvinus University of Budapest

De Massis, A., Sharma, P., Chua, H. J., Chrisman, J. J., Kotlar, J., 2012. Family business studies: An annotated bibliography. Cheltenham: Edward Elgar Publishing

European Parliament, 2015. Report on family businesses in Europe. (2014/2210(INI). Available

http://www.europarl.europa.eu/sides/getDoc.do?type=REPORT\&reference=A8-2015-0223 \&format=XML\&language=HU. Date of downloading: 4 January 2018.

European Commission, 2005. The new SME definition. User guide and model declaration. Enterprise and Industry Publication

EY, 2017. Family Business Yearbook 2017. Available at: https://familybusiness.ey-vx.com/insights/family-business-yearbook-2017.aspx. Date of downloading: 15 January 2018 
Family Business Network (FBN-H), 2017. The stages of development of family businesses. Working material.

Gersick, K. E., Hampton M. M., Ivan Lansberg, Davis, J. A. 1996. Generation to Generation: Life Cycles of the Family Business, Harvard Business School Press.

Matsuhashi, K., 2013. An introduction to the challenges \& rewards of family owned businesses. On-line: http://www.slideshare.net/kmatsu81/family-business-101. Date of downloading: 10/02/2016.

Miller, D., Breton-Miller, I., Lester, R. H., Canella, A. A. Jr., 2007. Are family firms really superior performers? Journal of Corporate Finance, 13, pp. 829-858. DOI:10.1016/j.jcorpfin.2007.03.004.

Nábrádi A., Bárány L., Tobak J., 2016. Generációváltás a családi tulajdonú vállalkozásokban: Problémák, konfliktusok, kihívások, elméleti és gyakorlati megközelítés. [Generational succession in family-owned businesses: Problems, conflicts, challenges, theoretical and practical approaches]. Gazdálkodás 5, pp. 427-461.

Nagy A., 2007. Analysis of the Expected Income of several family types. Abstract - Applied Studies In Agribusiness And Commerce 1 (1), pp. 49-51.

Nsehe, M., 2014. The 10 Leading Family Businesses in Africa. Available at: https://www.forbes.com/sites/mfonobongnsehe/2014/01/08/the-10-leading-family-business es-in-africa/\#6558e22e7c4a. Date of downloading: 22 January 2018

PwC, 2014. Private and family business in Russia: challenges and growth drivers for today and tomorrow. Available at: http://en.smb.gov.ru/files/images/PFBS_report_RUS_final.pdf. Date of downloading: 20 January 2018

PwC, 2017. Family Business Survey. New vines from strong roots. South African edition 2016/2017. Available

https://www.pwc.co.za/en/assets/pdf/family-business-survey-2016.pdf. Date of downloading: 22 January 2018

Ramadani, V., Hoy, F., 2015. Context and Uniqueness of Family Businesses. Family Businesses in Transition Economies, 9-37. DOI:10.1007/978-3-319-14209-8_2

Tagiuri, R., Davis, J. A., 1982. Bivalent Attributes of the Family Firm. Family Business Review, 9 (2), pp. 199- 208. DOI:10.1111/j.1741-6248.1996.00199.x

The 50 largest corporations by revenue and industry, 2016. https://www.datashown.com/blog/2017/1/4/the-50-largest-corporations-by-revenue-and-ind ustry. Date of downloading: 26 January 2018

Tobak, J, Nagy, A., Pető, K., Fenyves, V., Nábrádi, A., 2018. The main factors determining effective operation in case of a family business. International Journal of Entrepreneurial Behaviour and Research. 24 (6), pp. 1065-1074

vs.hu, 2015. Család? Vállalkozás? A legtöbben egyszerre csinálják [Family? Business? Most do it simultaneously]. Available at: https://vs.hu/gazdasag/osszes/csalad-vallalkozas-a-legtobben-egyszerre-csinaljak-0417\#! s2. Date of downloading: 5 February 2016

\section{Bio-notes}

Júlia Tobak, completed her PhD studies at the Faculty of Economics and Business Administration University of Debrecen. The main research field of her is the examination of the operation of businesses. As a young reseracher she focuses on the analysis and the strategic decisions of family owned entreprsises. She is participating the education of business economics, entrepreneurship, introduction of businesses and projectmanagement.

András Nábrádi is a Professor, CSc, PhD, Habil. of economics in the Faculty of Economics and Business, University of Debrecen, Hungary. The main directions of the research fields are related to the study of strategic management, problems of family owned business, 
sectorial economy, risk management and nowadays on collaborative platform-based economy. Member of the Public Body of the Hungarian Academy of Sciences (HAS), Chair of the Ag. economics Committee of the Agricultural Division of the HAS, in Debrecen Executive Board member of the International MBA Network 'AGRIMBA' (2000-2015) Elected president of European Society of Agronomy (2010-2012), Elected president of the Hajdú-Bihar County Division of Hungarian Association of Economists (2014). Editorial Board Member of Delhi Business Review (India), Economics of Agriculture (Serbia), The Annals of the University of Oradea Economic Sciences (Romania), Economic and Regional Studies (Poland), NUML International Journal of Business \& Management (Pakistan) Deputy editor of: Applied Studies of Agribusiness and Commerce APSTRACT (Hungary, Debrecen). Total number of his publications is 528, total number of citations is 1066 , Hirsch- Index is 13. 